\title{
Turkey's place in the path of the development of common energy politics of the European Union
}

\author{
Tülay Yıldırım \\ Yeniyuzyil University, Turkey \\ tulay.yildirim@yeniyuzyil.edu.tr
}

\begin{abstract}
Energy was one of the major dynamics used to build the European Community. Especially after the oil crises in 1970s, the Community embraced the principle of unification as a means to guarantee the security of oil resources and requirements. In order to protect the available conditions of the Union and increase development both geographically and politically, the Union needed more energy. A fundamental lack of energy resources, an increasing dependency on imported energy, environmental concerns, and the failure to build a stable European market economy were all factors that harmed the young Union and forced it to seek new avenues for oil resources. Turkey, with its geographical and geopolitical position, has been both a bridge and a terminal between the Middle Eastern and Middle Asian countries and the world market. Because of its unique position, Turkey plays an important role in Europe's energy policy.
\end{abstract}

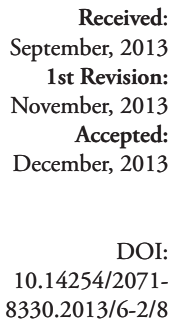
$8330.2013 / 6-2 / 8$

Keywords: EU, Turkey, Common Energy Policy.

JEL classification: F15, P28.

\section{INTRODUCTION}

Today, securing the energy supply is a major theme both in national and international politics and global capital circulations. Within the international structure, energy resources have become a fundamental element of power. Following the US and China, the European Union is the third-highest consumer of energy in the world (Hakk1, 2007, pp.117-19). The EU is also one of the main actors in the international energy market as an importer of oil and natural resources (Pamir, 2005, pp.67-71). With the latest wave of EU expansion, the 28-member Union has become more dependent on energy imports. The EU receives most of its energy supplies from the Russian Federation (Pamir, 2005, pp.67-71). China, with its quest to gain more energy resources, is viewed as a competitor with the EU. In short, the strongest members of the EU, those which aim at being an important actor in world energy policy, are aware of the fact that the issue of energy is tremendously crucial for Europe. For that reason, the EU has begun building a domestic energy market and increasing cooperation with Third World countries so that the Union can become an international actor with regard to energy (Kayac1, 2013). Within this framework, to rise above its energy problems, the EU has begun to emphasize projects with multiple pipelines. In order to finalize such projects, the EU 
gives special attention to Turkey. Since Turkey has a unique geographical position in terms of its proximity to important energy resources, it has an important role in the region. Its proximity to oil-producing locations like the Middle East, Black Sea and the Caucuses make it a relevant world player; Turkey is the bridge country among them. This study will discuss the following: the historical background of the EU's common foundation of energy policy, the reasons and needs for developing such a policy, the EU's current energy policy, and the role and place of Turkey in that current policy.

\section{THE HISTORICAL BACKGROUND OF THE EUROPEAN UNION'S COMMON ENERGY POLICY}

The EU's energy policy began in 1951 with the formation of the European Coal and Steel Union (ECSU) outlined in the Paris Agreement, which became a fundamental ideal of the EU. With the Rome Agreement signed in 1957, the European Atom Energy Union (EAEU) was founded. The purpose of the EAEU was to develop various cooperations for nuclear power and to provide possibilities for research in that field. Both agreements aimed to create free and integrated markets in the energy sector. Oil, natural gas and electric were under the responsibility of the European Economic Union (EEU) founded in the same year. Since then, European energy policy has developed parallel to the European economic integration process. Until 1974, none of the agreements addressed any specific energy type (Duran and Atik, 2007, p.388).

In the 1970s, the Union's energy policy was shocked by the oil crises. After experiencing the first oil crisis in 1973, the European Council produced "A New Strategy for Energy Politics" in 1974 that included plans to decrease energy consumption, to increase the security of energy supply and to protect the environment (Yorkan, 2009, p.26). The oil crises forced the Union to develop an energy strategy for the first time. Also, the Union decided to build a nuclear centre and search for alternative energy resources to reduce its dependency on oil.

With the second oil crisis in 1979, the Council needed to take further steps, so in 1980 they agreed on a set of specific aims that they would reach by 1990. These aims were based on the idea that member countries would decrease the consumption and importation of energy, would take energy saving efforts, and would integrate the Union's energy policy. After deciding on certain aims, the Union also tried to produce energy domestically and focused on constructing a "One Market" free-flow in the energy sector. In this context, the Union also realized that they needed to integrate the scattered available markets among the member countries and make their own domestic energy market competitive. During this time, environmental concerns also became important issues. The Union realized that producing and consuming energy caused harm to the environment, so they sought ways to diminish these harmful consequences. Following these efforts, between 1980 and 1990, the Union reduced its dependency on energy up to $10 \%$, and domestic energy production began competing with energy imports. These positive developments continued until 1995 (Yorkan, 2009, p.26).

On the other hand, as stated in the consensus in September 1986 and the report in 1988, the Council kept building its domestic energy market and followed more liberal energy policies (Yorkan, 2009, p.26).

With the collapse of the Soviet Empire in the beginning of the 1990s, the EU desired to guarantee its own energy security and took important steps. After the Cold War, with the Lahey Agreement (called the European Energy Necessities) signed in 1991, the EU projected and decided on more aims related to energy: to increase the security of energy supply, to increase productivity, transportation, distribution and usage of energy, and to take cautious steps for the environment. In order to reach to these aims, in 1998 the "Energy Necessities and Productivity" protocol was put into effect (Karluk, 2008, p.3). 
In 1995, "The White Book: An Energy Policy for the European Union" was published; it included the principles and aims of the EU domestic energy market. The White Book integrated energy issues produced in three founding agreements and the EUs founding agreement. The White Book also empasized the security of energy supply, environmental protection, and the power of competition.

The European Union Energy Policy expanded between 1998 and 2002. In 2000, the Green Book, which discussed the security of energy supply, was published. The Green Book discussed ways in which the European energy industry could become more competitive and how harmful gas emissions into the environment could be reduced. In this context, the EU worked on freeing energy resources regarding electric and natural gas. In 2002, at the Barcelona Summit, the EU decided to free energy resources regarding electric and natural gas, and to put such decisions into action for firms by 2005. After these developments, in November 2002, the Energy Council met, and with the approval of France and Germany, they decided to open the energy sector to the competitive market. Within this framework, the competitive markets of electric and gas opened to business sectors in July 2004 and to all consumers in July 2007. From July 2007 onward, all European citizens were given the capacity to choose their electric and gas suppliers freely (Kahraman, 2007, p.5).

In 2006, Ukraine and Russia faced natural gas crises, and these caused the EU to review its energy policy. Following these crises, the European Commission published a report to define its new energy policy. The Commission declared that the EU's security of energy supply was under risk and they needed to come up with solutions to restore it. In March 2006, the European Commission published an expanded Green Book that dealt with additional issues regarding energy policy; it outlined three necessary and major principles (Duran and Atik, 2007, p.389). These were:

- security of energy supply

- competitive energy systems

- environmental protection.

The EU's six areas of priority regarding energy, as stated in the Green Book, included:

- the construction of laws regarding the foundation of a European Energy Network, a European Connection Plan, and a European Energy Regulation Council

- the provision of energy supply security in the domestic market and cooperation among member countries

- the preparation of a strategic energy report, including issues of renewable energy and coal and nuclear energy, with a statement on the advantages and disadvantages of different energy resources

- the definition of global warming and what steps might be taken to avoid the dangerous consequences of it

- the design of a strategic energy-technology plan

- the formation of a common international energy policy

These new policies gradually unified the scattered energy politics among EU member states, and the EU's energy policy gradually became more unified. In short, the energy crises of the 1970s (and those of Russia and Ukraine much later) forced the EU to develop a common energy policy.

\section{THE ENERGY PROBLEMS OF THE EUROPEAN UNION AND THE NEW ENERGY POLICY}

One of the highest energy consumers in the world, the EU unfortunately lacks its own energy resources. With its 2007 expansion, the EU's dependency on energy import dramatically increased. The EU, because it 
consumes more than $25 \%$ of the world's industrial energy, will need more energy over time (Deveci, 2009, pp.26-29).

In 2010, total final energy consumption in the EU-27 reached 1,153,319 ktoe. In 1990, total consumption in the EU-27 was 1,078,628 ktoe. This equals a growth of $6.92 \%$ during the last twenty years (Hirl, Labanca and Bertoldi, 2013).

When we analys the figure 1 , the transport sector had the biggest share of total consumption $(31.67 \%)$ in the EU in 2010. The industry and service sectors were both smaller in terms of final energy consumption, with shares of $25.29 \%$ and $13.21 \%$ respectively. Residential energy consumption accounted for $26.65 \%$ of total final energy consumption in 2010. When we analyze the percentages based on different sectors, the highest energy consuming sector is transportation: one-third of total consumption. In the transportation sector, oil is obviously the major factor.

\section{Final energy consumption breakdown into sectors in the EU-27, 2010}

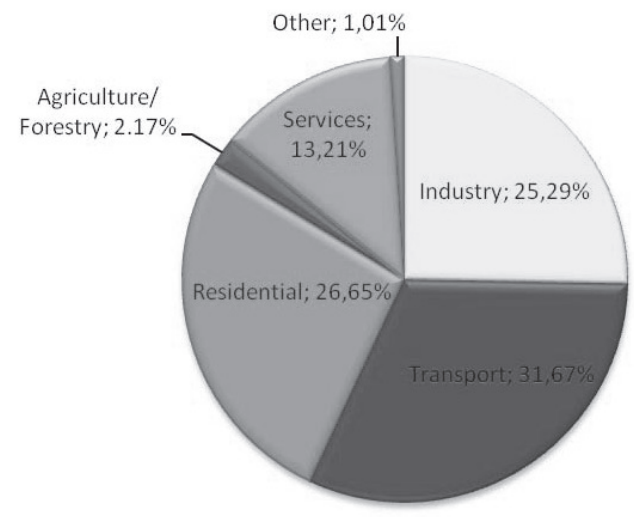

Figure 1: Energy consumption breakdown (source Eurostat)

Notwithstanding its efforts to increase energy productivity, the EU-27 is still an energy importer. As we observe in Figure 2, the EU's domestic resources are still insufficient to provide the EU's energy need for production. In 2011, the EU's energy dependency actually increased to 53.8\%. As examples, in 2011 the EU's import dependency for oil was $84.9 \%$, for natural gas $67.0 \%$ and for solid fuels $41.4 \%$. In $2011,12 \%$ of the EU's imported oil came from Russia and $12 \%$ from Norway; $30 \%$ of its imported natural gas came from Russia and 28\% from Norway for 28\%; $26 \%$ of its imported solid fuel came from Russia and $24 \%$ from Colombia (EU Energy in Figures, 2013).

In addition to its increased imported energy dependency, being dependent on only one supplier is also a real problem for EU countries. Estonia, Lithuania, Latvia, Bulgaria, the Slovak Republic, Ireland, Switzerland and Finland import 100\% of their natural gas from Russia. Greece, Hungary and Austria import 80\% of their natural gas from Russia. Lithuania, Hungary, the Slovak Republic, and Poland import 95\% of their oil from Russia (EU Energy in Figures, 2013). 
Table 1

EU-27 Energy Import Dependency

\begin{tabular}{|l|c|c|c|c|c|c|}
\hline \multirow{2}{*}{ By Fuel } & \multicolumn{5}{|c|}{ Import Dependency (\%) } \\
\cline { 2 - 7 } & 1995 & 2000 & 2005 & 2009 & 2010 & 2011 \\
\hline Total & $43.2 \%$ & $46.7 \%$ & $52.4 \%$ & $53.8 \%$ & $52.6 \%$ & $53.8 \%$ \\
\hline Solid Fuels & $21.4 \%$ & $30.5 \%$ & $39.2 \%$ & $41.1 \%$ & $39.4 \%$ & $41.4 \%$ \\
\hline Petroleum and Products & $74.3 \%$ & $75.7 \%$ & $82.2 \%$ & $83.2 \%$ & $84.1 \%$ & $84.9 \%$ \\
\hline Gas & $43.5 \%$ & $48.9 \%$ & $57.7 \%$ & $64.3 \%$ & $62.4 \%$ & $67.0 \%$ \\
\hline
\end{tabular}

Source: Eurostat

Today, the EU faces serious energy problems. As we see in Figure 2, the major problem is that the security of energy supply has gradually become more tenuous.

Based on Eurostat data, it is expected that by 2030 the EU's energy needs will be provided from the following: $27 \%$ from natural gas, 34\% from oil, 11\% from nuclear energy, 12\% from renewable energy resources, and 16\% from solid oil (European Energy and Transport,2007). Within this framework, although it is expected that the EU will be dependent on imported oil for $93 \%$ of its needs and natural gas for $84 \%$ of its needs, it is still very vague and unpredictable how and where the EU will provide these energy needs; this is a great concern(Ibid). Also, a major problem for the EU is that its major energy dependency is on Russian oil and natural gas; this is a potential threat for EU's security of energy supply, as Russian oil politics tend to be unstable at times.

Beginning in the 1980s, environmental issues have also posed serious concerns for the EU. From production to usage, the available energy systems were seen as a threat to the global environment, and it quickly became an issue how the energy systems could become more environmentally sound. By the end of 1980s, the EU faced the tendency to free the energy markets. In this context, the EU realized the necessity of uniting the scattered available markets of the EU countries. Later, the domestic energy market became the target of increasing competitiveness.

In order to solve these problems in the energy sector, the European Council beginning in 2007 took new steps. Troubling issues that were given particular attention included: increasing dependency in energy, high expenses for new investments, environmental and climate change, pollution, the use of renewable energy resources, and possible ways of increasing energy productivity. These issues were closely related to the EU's common political, social and economic concerns and ideals; soon they put into action.

In this context, in January 2007, the European Commission published a new report called "New Energy Politics for Europe," which included new aims and visions for the EU's energy issues. This report discussed concrete plans for the EU's new energy policy, and focused on increasing the security of energy supply, environmental protection and domestic market competitiveness. With this new energy report, the EU decided to implement higher goals for energy policy by 2020 , including: $20 \%$ of its energy need will come from renewable energy resources; $20 \%$ of vehicles will use biogasoline; a $20 \%$ increase in energy productivity; and further decreases in greenhouse gas emissions (since 1990, greenhouse gas emissions have decreased 20\%; by 2020, the EU hopes that they will decrease by 30\%) (Europe's Climate Change Opportunity, 2008). The EU's new energy policy-in addition to the new aims listed above-indicated that European citizens and the EU economy will be protected through investment in domestic energy sources.

The European Commission published its "Second Strategic Energy Review" declaration in November 2008, which focused on the security of energy supplies, increasing energy productivity, and decreasing the dependency on Russian oil and gas. This report was considered more concrete and achievable as an energy 
plan, and also more visionary. For example, the report included the EU's Energy Security and Solidarity Action Plan for 2050, which dealt with issues such as: providing and investing in more varieties of energy resources; emphasizing energy issues in international relations; improving oil and natural gas supplies; improving crisis management; and increasing energy productivity and improving energy resources.

In 2008, the European Commission published its "Second Strategic Energy Security and Cooperation Plan" and sent it to member states. In this plan, the Commission emphasized the Nabucco Project, concerning the Turkey-Greece-Italy pipeline. For the Commission, the Nabucco Project was a priority in terms of securing energy supply. This pipeline transports natural gas from the Middle East and Caspian basin throughout Turkey (the South Gas Corridor) and across Europe. This line will provide a great amount of Europe's future gas needs. In this report, the Commission also states that with common purposes and ideals the member states should cooperate with countries that produce and transport energy in those regions. It also emphasized that in the long run and as long as political conjecture allows, the EU can obtain large amounts of natural gas from other countries in the region, as well, such as Uzbekistan and Iran. Moreover, the Commission stated that the inclusion of Turkey, Moldova and Ukraine into the EU's Energy Union were necessary.

Although the EU has different supplier profiles, for historical reasons particular EU member states are $100 \%$ dependent on only one supplier. To adjust this, the EU plans to secure for its citizens electric and natural gas needs (in a 20-20-20 target) in the future. In order to do that, the EU plans to revise its energy infrastructure and give special attention to multiple-pipe projects. As such, the Commission's six new infrastructure projects and action plans include: the Baltic Interconnection Plan, the South Gas Corridor, the Mediterranean Energy Circle and Centre, the development of north-south gas and electric interconnections in southeast Europe, and the North Sea Network and Liquefied Natural Gas. These projects and action plans are major priorities for the Commission.

\section{THE ROLE AND IMPORTANCE OF TURKEY IN THE NEW EUROPEAN UNION ENERGY POLICY}

With its developing economy, expanding residential areas, and increasing use of natural gas, Turkey will need increased energy supplies. Even though its demands are lower than the big European states, Turkey has become an imporant consumer of energy over time (Energy Balance for Turkey, 2009). Turkey tries to invest in hydroelectric and renewable energy resources, but it still must import a high amount of energy. Turkey imports $30 \%$ of its natural gas and $60 \%$ of its oil from Russia. Russia is not only a major supplier for Europe but also for Turkey. Russia is an energy superpower in the world, and for that reason Turkey should always avoid disputes with Russia (2008 Yilı Enerji, 2009).

The EU imports more than the half of its energy, a fact that shapes the EU's international politics to reduce the risk of import. Because the EU searches for alternative energy suppliers and lines, this closely affects Turkey's security of energy supply. Turkey has open access to the Middle East, Black Sea, Caucuses, Middle Asia, and Gulf countries. These countries produce $70 \%$ of the world's oil and natural gas (Ercan, 2011, p.10). Because of its strategic position, Turkey transports oil and natural gas from these regions to Europe (Engür, 2008, p.40). This bridge position gives Turkey a political advantage with the EU, the nations of which are dependent on Turkey as an energy transporter. Because the EU wants to reduce its energy dependency on Russia, it wants to reach out to the oil and natural gas resources of the Caspian region, the Caucuses, North Africa and the Middle East. Moreover, the EU and Turkey share the disadvantage that they are both dependent on oil and natural gas imports. This shared disadvantage should bring them closer. 
In order to provide security for energy supply and to acquire alternative suppliers, the EU prefers multiple pipeline projects. The ultimate future plan of the EU is to reduce dependency on Russian oil and natural gas, and instead reach out to Middle Eastern resources. As this begins to happen, Turkey's position and role will increase substantially as an energy corridor. When we closely look at INOGATE's's offer for alternative oil and natural gas pipelines, we can clearly see Turkey's role in that plan.

The oldest pipeline in Turkey is an Iraq pipe line which carries oil from Kirkuk to the west. While in 1999 this pipeline carried 305 million barrels of raw oil, in 2006 this amount went down to 10.9 million barrels owing to acts of sabotage (Ercan, 2011, p.10). The construction of the Bakü-Tiflis-Ceylan pipeline began in 2003 and went into use in 2006 (Nabucco Boru Hatt1, 2013). This pipeline goes through Georgia and Turkey and carries Azeri oil from the Caspian region. Finally, in Turkey (from Ceyhan), the oil is distributed to the world market. There were various projects prepared in Turkey for this pipeline and natural gas transportation (Kantörün, 2010). For example, the Bakü-Tiflis-Erzurum project has been functioning since 2006. The other pipeline project is the Tebriz-Erzurum line; since 2001, it has transported Iranian natural gas to Turkey.

Besides these projects, Turkey takes important roles in the Trans-European energy network. One of the important projects in this network is the NABUCCO project. With this project, the natural gas taken from the Middle East will be transported through Turkey, Romania and Hungary, and then collected in Austria as the distribution centre. The NABUCCO project is 3,400 km long and is expected to transport 25-30 billion cubic meters of natural gas every year (Nabucco Boru Hatt1, 2013).

The NABUCCO Project is considered a relieving option for the EU, which has been concerned about its energy dependency on Russia. If Middle and Eastern European countries can show political strength and provide natural gas through this pipeline, it would bring some sort of solution for the region's oil dependency. This solution, however, can only be possible with Iraqi and Iranian natural gas in addition to natural gas from Azerbaycan and Egypt. In these solution plans, with its geopolitical location between the East and the West as a natural energy bridge, Turkey is the only secure transit option for carrying energy resources from the Middle East and Caspian basin to the world market.

The second project in which Turkey has taken a role is South Eastern Gas Ring Project. With this project, South Caspian, Middle Eastern and southern Mediterranaen natural gas will be carried to the EU. The first leg of this project, the Turkey-Greece line, has been in use since 2007. It is planned that the GreeceItaly line will be in use by 2018, bringing natural gas to the Italian market (Üstün, 2013, p.23). This is one of the most important projects in providing natural gas to Europe.

Another important reason why Turkey has a substantial role as an energy corridor owes to the political situations of Iran, Qatar and Iraq. Although their governments seem to be in opposition to the West, their natural resources force them to maintain relationships at state levels. The world's fourth most important oil producer and owner of $10 \%$ of the world's oil reserves is Iran (Country Analysis Brief: Iran, 2013). Qatar is also an important natural gas producer in the Gulf Region with its 25 trillion cubic meters of reserves. Countries in the Far East import their natural gas from Qatar, but only one European country, Spain, purchases a significant amount of LNG from Qatar (Country Analysis Brief: Qatar, 2013). With the increasing

The INOGATE Program is an international energy co-operation programme between the European Union and the Partner Countries of Armenia, Azerbaijan, Belarus, Georgia, Kazakhstan, Kyrgyzstan, Moldova, Tajikistan, Turkey, Turkmenistan, Ukraine and Uzbekistan. They have agreed to work together toward achieving the following four major objectives 1) Converging energy markets on the basis of the principles of the EU internal energy market taking into account the particularities of the involved countries 2) Enhancing energy security by addressing the issues of energy exports/imports, supply diversification, energy transit and energy deman 3) Supporting sustainable energy development, including the development of energy efficiency, renewable energy and demand side management 4)Attracting investment towards energy projects of common and regional interest.) 
capacity of Qatar's production and alternative pipeline possibilities (and the formation of Nabucco); Europe will decrease its oil and natural gas dependency on Russia. In addition, the oil reserves of Iraq (28 billion tons) continue to function as a major supplier for Europe. As it happened with Iran, most of Iraqi oil goes to the East; only 20\% of it goes to Europe (Country Analysis Briefs: Iraq, 2013). With this in mind, it is very crucial for Europe's big countries to be active in the region and to reach out to alternative energy resources aside from Russia. Again, Turkey's role as an energy corridor is very important in this respect.

Turkey, as an energy bridge with available pipelines already reaching the European Market, should be a great help as the EU integrates its domestic energy. In the coming years, Turkey's important role will gradually increase with completed pipeline projects.

\section{RESULTS}

Today, rapidly increasing energy needs cause the world states to search for new and alternative resources. The resource suppliers of the EU might not be enough for future needs, and the EU will have to import more oil and natural gas. As most EU countries are dependent on Russian energy, this is problematic for the security of energy supply. For that reason, the EU needs to reach out to alternative energy resources aside from Russia. At this point, Turkey's role as an energy bridge between the EU and alternative (and new) energy resources should become more and more critical.

In order for this happen, two necessary conditions are already available for the EU. The adequate amount of natural gas and oil available in Caspian-Caucuses region and the Middle East will be transported through a pipeline in Turkey. Turkey's role is especially important for Caspian energy resources. As for the Middle East and Gulf energy resources, Turkey is clearly the best route through which to transfer natural gas to Europe.

Within this plan and framework, there are important pipeline projects that secure Turkey's role as an energy corridor, including the Turkish-Iraqi natural gas line and the Turkish-Egyptian-Iranian oil and natural gas lines. Moreover, the Turkish Straits are the international transit route for Russian and Middle Asian oil, as well as oil from the Turkic Republics. An additional transit route under Turkish control is the Azerbayjan, Kazakhistan and Iraq oil pipeline through Iskenderun Bay. When all of the pipeline projects are completed, such as Nabucco, they will be connected to a network in Turkey.

In general, Turkey and the EU have the same energy politics. The EU desires not to be dependent on the energy resources of any particular country, and Turkey desires to take a more powerful position in the international oil market. It bears repeating that Turkey holds an important location and role in terms of the EU and the West's energy politics. By putting the alternative pipeline projects into action, Turkish- EU relations will gain momentum. In other words, if the EU chooses not to develop any other energy transportation projects, it will be working closely with Turkey for a long time.

\section{REFERENCES}

Hirl, B., Labanca, N., Bertoldi, P. (2013), Energy Effciency Status Report 2012, European Commission. 2008 Yılı Enerji Sektör Raporu (2009), BOTAŞ, Ankara.

Cohen, A. (2007), Europe's Strategic Dependence on Russian Energy, Heritage Foundation, Backgounder, No. 2083.

Deveci, B. (2009), Doğal Gaz Krizi ve AB’nin Enerji Politikası, Bülten, 42.

Duran, C. \& Atik, H. (2007), Avrupa Birliği, Gümrük Birliği ve Türkiye, Nobel Yayınları, Ankara. 
Engür, E. (2008), Doğu -Bati Enerji Koridoru Doğal Gaz ile Tamamlanıyor: BOTAŞ’IN Avrupa“ya Acilim Stratejisi, Avrasya Dosyası, Vol. 9, No. 1.

Hakkı, I. (2007), Turkiye-Avrupa Birliği İliskilerinin Geleceği Acısından Avrupa Birliği Enerji Güvenliği Sorunu, Uluslararası Ekonomi ve Dıs Ticaret Politikaları, Vol. 1, No. 2.

Ercan, M. (2011), Avrupa Birliği’nin Enerji Politikasında Türkiye’nin Önemi, Akademik Bakı̧̧ Dergisi, Vol. 25.

Kahraman, M. (2007), Avrupa Birliğine doğru, Enerji Politikası, Kütahya Ticaret ve Sanayi Odası dergisi, Vol. 12.

Kantörün, U. (2010), Avrupa Birliği ve Türkiye’nin Enerji Politikalar,, Bilgesam, available from: < www.bilgesam.com> (17 April 2010).

Karluk, R. (2008), Küreselleşen Dünyada Avrupa Birliği”nin Orta Asaya Ülkeleri ile Olan İlişkileri veBölgeye Yönelik Strateji, Anadolu Üniversitesi, İktisadi ve İdari Bilimler Fakültesi dergisi, Vol. 5, No. 1.

Kayacı, F., AB’nin Enerji Politikası ve Bu Politikanın Gelisimi, available from: <http://www.foreigntrade.gov.tr/ab/CesitliCalismalar/AB\%20Enerji.htm> (19 July 2013).

Pamir, N. (2005), Enerji Politikaları ve Kuresel Gelismeler, Stratejik Analiz, December.

Özder, A. (2000), Avrupa Ekonomik Konseyi Bölgesinde Sürdürülebilir Enerji Politikaları, Ekonomi dünyası, Vol. 29.

Üstün, Ç. (2013), Energy Cooperation between Import Dependent Countries: Cases of Italy and Turkey, Perceptions Journal of International Affairs, Vol. 16, No. 1.

Yorkan, A. (2009), Avrupa Birliği’nin Enerji Politikası ve Türkiye’ye Etkileri, Bilge Stratejileri, Vol. 1, No. 1.

European Comission (2007), "European Energy and Transport" Trends to 2030, available from: http://ec.europa.eu/energy/observatory/trends_2030/doc/trends_to_2030_update_2009.pdf (11 August 2013).

European Comission (2008), 2020 by 2020 Europe's Climate Change Opportunity, available from: <http://eur-lex.europa. eu/LexUriServ/LexUriServ.do?uri=COM:2008:0030:FIN:en:PDF> (06 August 2013).

EU Energy in Figures Statistical pocketbook 2012, available from: <http://ec.europa.eu/energy/publications/doc/2013 pocketbook.pdf> (11 July 2013).

EU Energy Country Statistic 2012, available from: <http://ec.europa.eu/energy/observatory/countries/doc/2012-countryfactsheets.pdf> (11 July 2013).

2009 Energy Balance for Turkey, available from: <http://www.iea.org/stats/balancetable.asp?COUNTRY_CODE=TR> (19 July 2013).

Country Analysis Brief: Iran, US Energy Information Administration (2013), available from: <http://www.eia.gov/countries/analysisbriefs/Iran/iran.pdf> (09 August 2013).

Country Analysis Brief: Qatar, US Energy Information Administration (2013), available from: <http://www.eia.gov/countries/analysisbriefs/Qatar/qatar.pdf> (09 August 2013).

Country Analysis Briefs: Iraq, US Energy Information Administration (2013), available from: <http://www.eia.gov/countries/analysisbriefs/Iraq/iraq.pdf> (09 August 2013).

Nabucco Boru Hattı Projesi, available from: <http://tr.wikipedia.org/wiki/Nabucco_Boru_Hatt\%C4\%B1_Projesi> (13 August 2013). 